\title{
DISCHIDIA (APOCYNACEAE, ASCLEPIADOIDEAE) IN LAOS AND VIETNAM
}

\author{
TATYANA LIVSHULTZ ${ }^{1}$, TRAN THE BACH ${ }^{2}$, \\ SOMCHANH BOUNPHANMY ${ }^{3} \&$ DANIEL SCHOTT ${ }^{4}$
}

\begin{abstract}
SUMMARY
Two new species, Dischidia dohtii Tran \& Livsh. and D. cornuta Livsh., are described and illustrated. Dischidia rimicola Kerr is illustrated for the first time. All three species are associated with treenesting ants of the genus Crematogaster. Presentation experiments with seeds of $D$. rimicola indicate that they are attractive to the ants. The possible affinity between $D$. dohtii and the enigmatic $D$. khasiana Hook.f. from north-eastern India is discussed; $D$. khasiana is lectotypified. A key to the 14 species of Dischidia documented from Vietnam and Laos and a list of exsiccatae are provided.
\end{abstract}

Key words: Dischidia, Apocynaceae, Asclepiadaceae, morphology, taxonomy, ecology, ant plant.

\section{INTRODUCTION}

The genus Dischidia R.Br. comprises approximately eighty species of epiphytic vines in Indochina, Malesia, Melanesia, and the east Pacific. Many species grow on the nests of arboreal ants (Kaufmann et al., 2001 and references therein). Species of section Ascidophora K. Schum. have highly modified pitcher leaves that function as ant houses (Janzen, 1974). While it has recently been the subject of floristic treatments (Rintz, 1980; Li et al., 1995; Forster et al., 1996; Jagtap \& Singh, 1999) and studies of its ecological associations with ants (Treseder et al., 1995; Kaufmann et al., 2001), both the taxonomy and ecology of Dischidia remain poorly understood through most of its range. We made field observations on three species in the highlands of Laos, including two that are here described as new. One of these, Dischidia cornuta, is known only from Laos; the other, Dischidia dohtii, also occurs in Vietnam. The third species, Dischidia rimicola Kerr, was previously known only from Thailand (Kerr, 1939; Craib \& Kerr, 1951) but occurs also in Vietnam and Laos. We illustrate D. rimicola for the first time and provide a detailed description, including the first description of its fruits and seeds.

1) Arnold Arboretum, Harvard University Herbarium, 22 Divinity Ave., Cambridge, MA 02138, USA; e-mail: tlivshul@ oeb.harvard.edu.

2) Department of Botany, Institute of Ecology and Biological Resources, Hoang Quoc Viet, Cau Giay, Ha Noi, Vietnam; e-mail: tranthebach@yahoo.com.

3) National University of Lao, Faculty of Science, Department of Biology, P.O. 7322, Vientiane, Laos; e-mail: somchanhb@yahoo.com.

4) Department of Molecular and Cell Biology, Harvard University, Cambridge, MA 02138, USA; e-mail: dhs@mcb.harvard.edu. 


\section{MATERIALS AND METHODS}

Herbarium specimens from A, BH, BISH, BKF, BRIT, C, CAL, F, G, HN, K, KEP, L, M, MO, NY, P, PH, PNH, SING, UKM, and US were examined. Observations were made on living, herbarium, and alcohol preserved specimens. For SEM, flowers were preserved in FAA and stored in $70 \% \mathrm{EtOH}$, dissected, put through a dehydration series, critical point dried, mounted on aluminium stubs with two-sided tape, coated with gold-palladium, and viewed with a Zeiss 960 SEM. All photography is digital. Some images were re-touched to remove charge lines, debris, cracks in the background, and small nicks; re-touching did not alter the morphology or micro-morphology depicted in the images. Distribution of sclerenchyma in the anthers was determined by staining preserved or reconstituted flowers with phloroglucinol-HCl.

Seed presentation experiments were conducted at Nong Khoum Khiaou, 15.20 N, 106.32 E, 1000 m, at Thongset Village, Champasak Province, Laos in January 2000. The forest, at $1000 \mathrm{~m}$, is very open and shrubby, with parts converted to agricultural land. Each experiment consisted of placing a small plastic dish with five D. rimicola seeds with their coma removed, five achenes of Elephantopus spec. (Asteraceae) of similar size and shape, and five pieces of silica gel (as an inert control) near a nest of Crematogaster spec. C with $D$. rimicola growing in it, and noting the time of removal of each object. Observations were stopped 10 minutes after ants removed all Dischidia seeds or all of one type of object. We found four accessible nests, two of these were disturbed when discovered and the ants' response to placement of the dish near their nest was to stay inside the nest (first nest) or to ignore the dish and continue transporting pupae from one part of the nest to another (second nest). Thus the experiment was conducted with two nests only.

\section{RESULTS}

\section{ECOLOGY}

Dischidia cornuta, $D$. dohtii, and $D$. rimicola grow sympatrically in an open, secondary, Fagaceae-dominated forest, at $1000 \mathrm{~m}$ on the Bolaven Plateau in Laos. Dischidia rimicola also occurs in the lower canopy of a nearby primary, closed canopy, mixed deciduous forest. Dischidia species are much more visible at the first site but relative abundance in the two habitats is unclear without surveying the canopy of the second. Dischidia cornuta and D. dohtii are associated with Crematogaster spec. A (Livshultz 00-31, 00-34); D. rimicola was collected from the nests of Crematogaster spec. B (Livshultz 00-20) and Crematogaster spec. C (Livshultz 00-22, 00-27, 00-29, all ant specimens deposited at Cornell Entomological Museum). No ants were found on the plant collected from the primary forest. Because $D$. rimicola grows from a single root stock, the ant nest was easily located, in a knot in the host tree. Larvae and pupae were distributed among the roots of a plant pulled from a nest. Dischidia cornuta and D. dohtii form large mats on the host tree. Ants were abundant on the plants, but the nests were not located. No larvae or pupae were found on the branches removed for specimens.

In presentation experiments of $D$. rimicola seeds, Crematogaster $\mathrm{spec}$. $\mathrm{C}$ removed all D. rimicola seeds but took only one Elephantopus spec. achene and none of the silica gel pieces (Fig. 1). We did not observe the final location of all of the objects removed, 

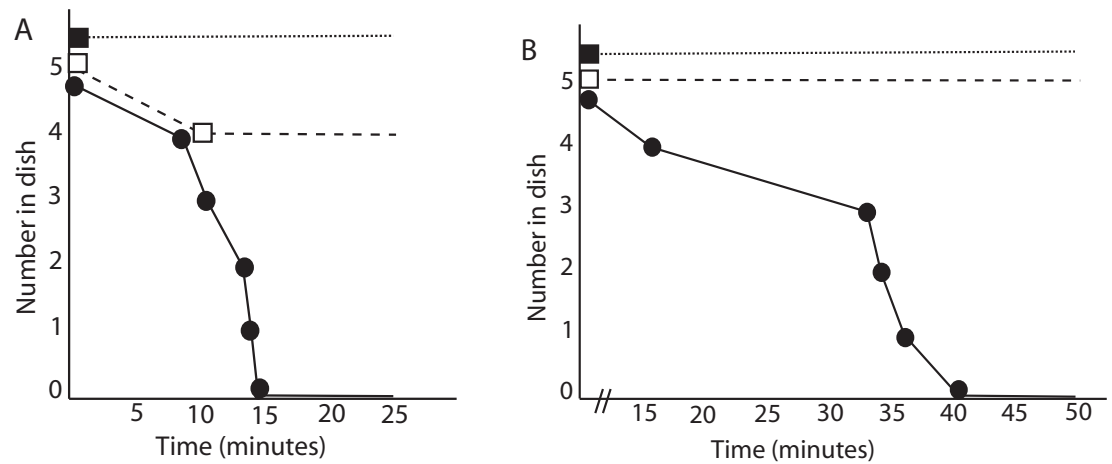

Fig. 1. Ants preferentially removed Dischidia rimicola seeds compared with Elephantopus spec. achenes in two Crematogaster spec. C nests tested ( $\mathrm{p}=0.05$ in nest $\mathrm{A}$ and $\mathrm{p}=0.005$ in nest $\mathrm{B}$ in onetailed Mann-Whitney U tests). We placed five D. rimicola seeds (filled circles) Elephantopus spec. achenes (unfilled squares) and silica grains (filled squares) in a small plastic dish near each nest.

but in both experiments we observed ants carrying Dischidia seeds into the nest. The trivial explanation for these observations is that Elephantopus spec. achenes are distasteful to ants. But the combination of these observations with the spacial association of D. rimicola with ant nests, supports the hypothesis that the Dischidia seeds are attractive to ants, and that this attractiveness is the basis of the ant/plant association.

Our observations agree with both experimental and informal observations of other Dischidia species (Kaufmann et al., 2001 and references therein; Kleijn \& Van Donkelaar, 2001). A phylogenetic analysis of Dischidia (Livshultz, 2003a) shows that the occurrence of ant-associations is widespread in the genus and not limited to any single clade. Many species of Hoya, the sister genus of Dischidia, also form ant associations (Kaufmann et al., 2001 and references therein; Kleijn \& Van Donkelaar, 2001). The wide distribution of ant-associations in Dischidia and Hoya suggests that this trait could be plesiomorphic in these epiphytes. To test this hypothesis we need a well-resolved phylogeny for the two genera and ecological data from their c. 200 species. Identification of the chemical basis for the attractiveness of Dischidia and Hoya seeds to ants would allow us to better define the trait 'ant-association', make more precise hypotheses about the homology of this trait between the two genera, and perhaps (depending on the lability of the chemicals) permit us to assay seeds from herbarium specimens of species for which there are no field observations.

\section{TAXONOMY}

A total of 14 species of Dischidia, thirteen native and one cultivated, are documented by herbarium specimens from Vietnam and Laos (Table 1). Of the native species, five are recorded from both countries, seven are recorded from Vietnam but not Laos, and one is recorded from Laos but not Vietnam. Given the paucity of collections, especially from Laos, it is likely that most of these species actually occur in both countries. Six of these species occur in both Indochina and Malesia (Rintz, 1980) while the other seven are endemic to Indochina (Craib \& Kerr, 1951; Pham-hoang, 1993), including two new species, D. cornuta and $D$. dohtii. A list of exsiccatae is presented. 
Table 1. Dischidia species in Laos and Vietnam $(*=$ endemic to Indochina $)$.

\begin{tabular}{lcc}
\hline Species & Laos & Vietnam \\
\hline D. acuminata Costantin* & - & + \\
D. acutifolia Maingay ex Hook.f. & + & + \\
D. bengalensis Colebr. & - & + \\
D. cornuta Livsh.* & + & - \\
D. dohtii Tran \& Livsh.* & + & + \\
D. griffithii Griff. ex Hook.f.* & - & + \\
D. hirsuta (Blume) Decne. & - & + \\
D. imbricata (Blume) Steud. & - & + \\
D. major (Vahl) Merr. & + & + \\
D. nummularia R.Br. & + & + \\
D. oiantha Schltr. (endemic to Philippines) & cultivated & + \\
D. rimicola Kerr* & + & + \\
D. tonkinensis Costantin* & - & + \\
D. tricholoba Kerr* & - & + \\
\hline
\end{tabular}

\section{KEY TO DISCHIDIA IN VIETNAM AND LAOS}

1a. Root-filled pitcher leaves present. Corolla abaxially puberulous, yellow and green, longitudinally striped, with purple lobe tips ............ major

b. Root-filled pitcher leaves absent. Corolla abaxially glabrous (may be papillate), white, off-white, pale yellow, pinkish, purple, with or without purple lobe tips, but never yellow and green striped $\ldots \ldots \ldots \ldots \ldots \ldots \ldots \ldots \ldots \ldots \ldots \ldots \ldots \ldots \ldots \ldots$

2a. Leaves reniform, wider than long, older leaves with adaxial surface convex, green, abaxial surface concave, purplish red; white wax chimneys on abaxial leaf surface present (for chimneys see Fig. 2C; photograph and description in Livshultz

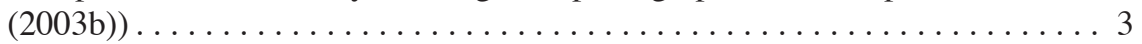

b. Leaves orbicular, elliptic, ovate, lanceolate, obovate, spathulate, or linear, rarely (D. dohtii) wider than long, older leaves plano-convex, biconvex, or only slightly succulent, both surfaces green. White wax chimneys on abaxial leaf surface present

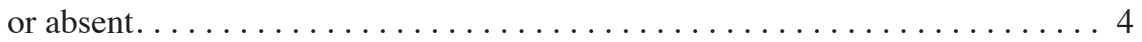

3a. Staminal corona lobes reduced to two minute bumps, appearing as absent .....

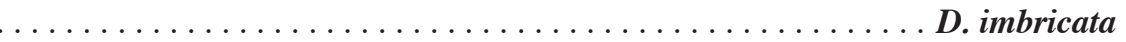

b. Staminal corona lobes present as two cylindrical arms, $0.2 \mathrm{~mm}$ long, prominent .

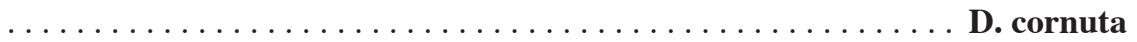

4a. Corolla 6-7 mm long, dark purple with pink or cream lobes, with two distinct rings of hairs adaxially, one at throat, the second below, at the level of the anthers ....

D. hirsuta

b. Corolla up to $5 \mathrm{~mm}$ long, white, cream, yellowish, or pinkish, adaxially glabrous or with a single zone of hairs on lobes or at throat $\ldots \ldots \ldots \ldots \ldots \ldots$

5a. Plants lanate with hairs to $0.9 \mathrm{~mm}$ long. Staminal corona of minute, unstalked

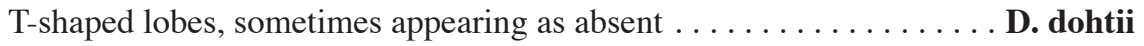

b. Plants glabrous to tomentose, hairs less than $0.2 \mathrm{~mm}$ long. Staminal corona of prominent, stalked lobes, always evident $\ldots \ldots \ldots \ldots \ldots \ldots \ldots \ldots \ldots \ldots \ldots \ldots \ldots$ 
6a. Staminal corona lobes sagittate, apices obtuse or acute. Leaves and stems lacking wax chimneys, not farinose although exfoliating epicuticular wax is sometimes apparent on herbarium specimens . . . . . . . . . . . . . 7

b. Staminal corona lobes anchor-shaped, apices retuse. Leaves and stems often with wax chimneys, farinose (wax may not be apparent on very young or mesic stems or on herbarium specimens where epicuticular wax has flaked off) . . . . . 11

7a. Corolla lobes pubescent near middle with antrorse hairs, throat glabrous . . . 8

b. Corolla lobes glabrous, throat with ring of hairs . . . . . . . . . . 9

8a. Mature stems and calyces usually glabrous, occasionally with a few hairs. Corolla 4.8-5 mm long, no longitudinal ribs on adaxial sides of corolla lobes, bases of

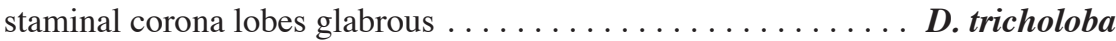

b. Mature stems and calyces usually tomentose, stems occasionally glabrescent. Corolla 3.5-4 mm long, with longitudinal ribs on adaxial sides of corolla lobes, with prominent tufts of hairs at bases of staminal corona lobes ... D. rimicola

9a. Prominent lobes on adaxial surface of corolla (corolline corona) in corolla lobe sinuses present. Staminal corona lobes fleshy, saddle-shaped, each with a prominent, transverse abaxial ridge. Pollinarium with caudicles shorter than corpuscle (see Fig. 4F for pollinarium terminology). Leaves usually obovate, occasionally

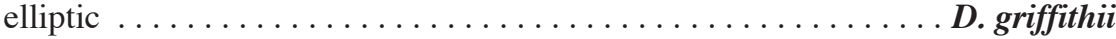

b. No lobes on adaxial surface of corolla (corolline corona absent). Staminal corona lobes membranous, without abaxial ridges. Pollinarium with caudicles longer than corpuscle. Leaves elliptic or lanceolate (rarely obovate) . . . . . . . . . 10

10a. Inflorescence with (1-)2-5 branches (look at older inflorescences with elongate branches), each plant with some inflorescences with 3 or more branches. Peduncles

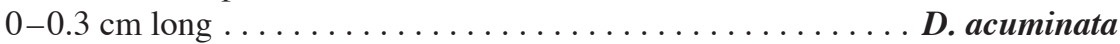

b. Inflorescences unbranched, rarely with 2 branches. Peduncles $0-3.2 \mathrm{~cm}$ long . . D. acutifolia

11a. Leaves orbicular, broadly ovate or elliptic, always less than $1.5 \mathrm{~cm}$ long. Corolla lobes widely divergent at anthesis, with only slightly thickened tips. Apex of staminal corona lobe entire. Fruit lanceolate, reflexed (forming a $90^{\circ}$ angle or less with the pedicel), (1.5-)2.5-3.7 by $0.2-0.5 \mathrm{~cm} \ldots \ldots \ldots$ D. nummularia

b. Leaves ovate, elliptic, spatulate, obovate, or linear; almost every specimen with some leaves over $2 \mathrm{~cm}$ long. Corolla lobes convergent at anthesis, with prominent cucullate thickenings at tips. Apex of staminal corona lobe emarginate or with a papilla in the centre. Fruit linear, not reflexed (forming a c. $180^{\circ}$ angle with pedicel) (may be reflexed on herbarium specimens due to distortion during pressing),

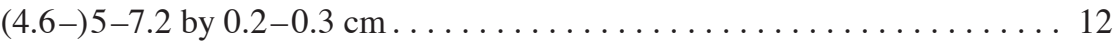

12a. Leaves linear, narrowly elliptic to spatulate, blades $1.8-5$ by $0.2-0.7 \mathrm{~cm}$, length to width ratio $3.8-16 \ldots \ldots \ldots \ldots \ldots \ldots \ldots \ldots \ldots \ldots \ldots \ldots \ldots \ldots$ bengalensis

b. Leaves broadly elliptic to obovate, blades $1.2-4.2$ by $0.7-3 \mathrm{~cm}$, length to width

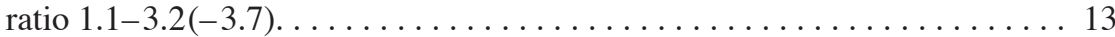

13a. Leaves predominantly elliptic, more rarely obovate, blades $1.2-3$ by $0.7-1.8 \mathrm{~cm}$, apex mostly obtuse or acute, rarely truncate or retuse. - Native D. tonkinensis

b. Leaves predominantly obovate, rarely elliptic, blades $3-4.2$ by $1-3 \mathrm{~cm}$, apex often truncate to retuse, occasionally obtuse, rarely acute. - Cultivated, native to the

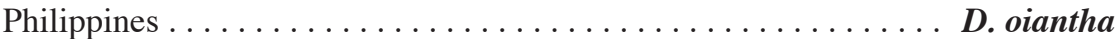



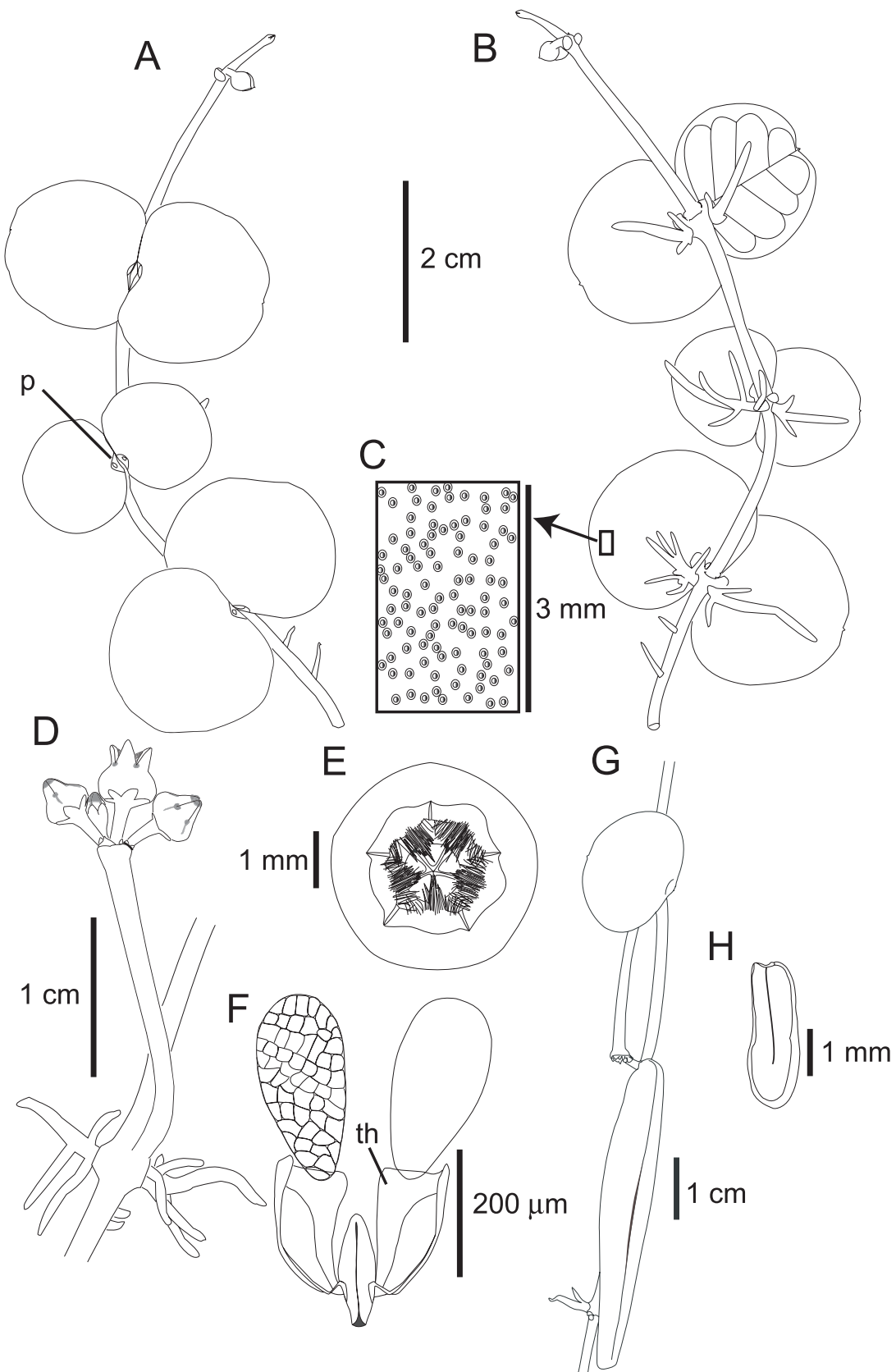

Fig. 2. Dischidia cornuta Livsh. A. Adaxial surface of vegetative shoot; B. abaxial surface of vegetative shoot; C. wax chimneys on abaxial leaf surface; D. inflorescence at node with aborted leaves, distribution of red pigment on corolla depicted with grey; E. flower at anthesis, viewed from above; F. pollinarium; G. shoot with infructescence; H. seed without coma (A-F: Livshultz 02-50; G: Livshultz 03-40; H: Poilane 12136). $\mathrm{p}=$ protuberance at base of leaf blade, th $=$ thickening on the inner margin of caudicle. Drawn by T. Livshultz. 
Dischidia cornuta Livsh., spec. nov. - Fig. 2, 3A-E

Dischidiae imbricatae affinis sed fauce corollae aperta, lobis coronae corollinis cordatis, appendicibus connectives antherarum apicem capitatis stylini tectantibus, lobis staminalibus prominentibus coronae brachiis longis praeditis, et marginibus antherarum dissimiliter formatis differens. - Typus: Livshultz 02-50 (holo BH, iso A, L, MO, National University of Lao), cultivated, field data: Laos, Champasak Province, Ban Thongset, Nong Khoum Khiaou, 15.20 N, 106.32 E, 1000 m, 21 Aug. 2002.

Plants succulent, herbaceous, epiphytic (or epilithic fide Poilane 12136) vines, matforming root-climbers or twiners when without support. Roots on mature plants adventitious, always paired below each node, each root emerging opposite a leaf within 1 or 2 elongate internodes on an actively growing stem, proliferating when in contact with a suitable substrate, additional adventitious roots occasionally produced along the internodes. Latex white. Indumentum glabrous except for very sparse hairs near the margins of some younger leaves and long retrorse hairs on the corolla lobes. Wax chimneys present, apparent within 2 elongate internodes on an actively growing stem, most prominent on abaxial surfaces of leaves; older stems, leaves, and peduncles farinose. Stems terete, 1-2 mm diam., internodes 2-6 cm long; twining stems with longer internodes and reduced or aborted leaves. Stipular colleters paired, triangular or ovate, to $0.1 \mathrm{~mm}$ long, inserted on either side of each petiole. Leaves always opposite, decussate early in development, becoming distichous, peltate at maturity; petiole 1-2 by 1-2 $\mathrm{mm}$; lamina with slightly reflexed margins early in development, concavoconvex at maturity (the adaxial surface convex and the abaxial surface concave); the abaxial side held appressed to the substrate by the adventitious roots and becoming purple with age, $1.2-2.3$ by $1.5-3 \mathrm{~cm}, 1-2 \mathrm{~mm}$ thick, transverse ovate to reniform, apex obtuse to retuse, minutely apiculate, base truncate to slightly cordate, with a small, colleter-bearing protuberance on the adaxial side; protuberance of a mature leaf with 1 or 2 colleters, purple; venation obscure in living plant, evident on abaxial surface of herbarium specimens, brochidodromous, with 3 or 4 pairs of secondaries. Inflorescence extra-axillary, umbelliform or compound-umbelliform, persistent through many flowering cycles; peduncles $1-3.5$ by $0.1-0.15 \mathrm{~cm}$, bearing 1 or 2 condensed axes at their apices; axes $2 \mathrm{~mm}$ diam., elongating to $4 \mathrm{~mm}$ long, with extremely short internodes, each with 3 or 4 flowers and buds at various stages of maturity when actively growing, fewer flowers often observed on herbarium sheets and young or quiescing inflorescences; lower portions of axes covered with transversely elliptical scars where flowers have fallen. Flowers subtended by two membranous triangular to lunate bracts c. 0.5 by $0.5 \mathrm{~mm}$, the bracts becoming chartaceous, persistent after flowers senesce, but wearing off from the oldest parts of the axes. Pedicels $3-4$ by $1 \mathrm{~mm}$, pale green. Calyx lobes quincuncial in bud, 1.5 by $0.7 \mathrm{~mm}$, ovate, apex obtuse, pale green with hyaline margins, glabrous, without colleters inside sinuses. Corolla tube succulent, full of nectar, urceolate, 4 by $3.8 \mathrm{~mm}$ at widest diameter, widest $0.5 \mathrm{~mm}$ from the base, obscurely 5-angled, without ribs, dull pale yellow, reddish on the tips, margins, and in the sinuses of the abaxial surface of the corolla lobes, sometimes with a faint reddish stripe on the tube below each sinus, red more prominent in buds than in mature flowers. Corolla lobes valvate in bud, 1.5 by $0.9 \mathrm{~mm}$, triangular, succulent, tips only slightly thickened, abaxially with stomate-bearing papillae, adaxially with long, straight, retrorse hairs, on tips and margins, divergent at anthesis, throat 1.5-1.8 mm diam., 

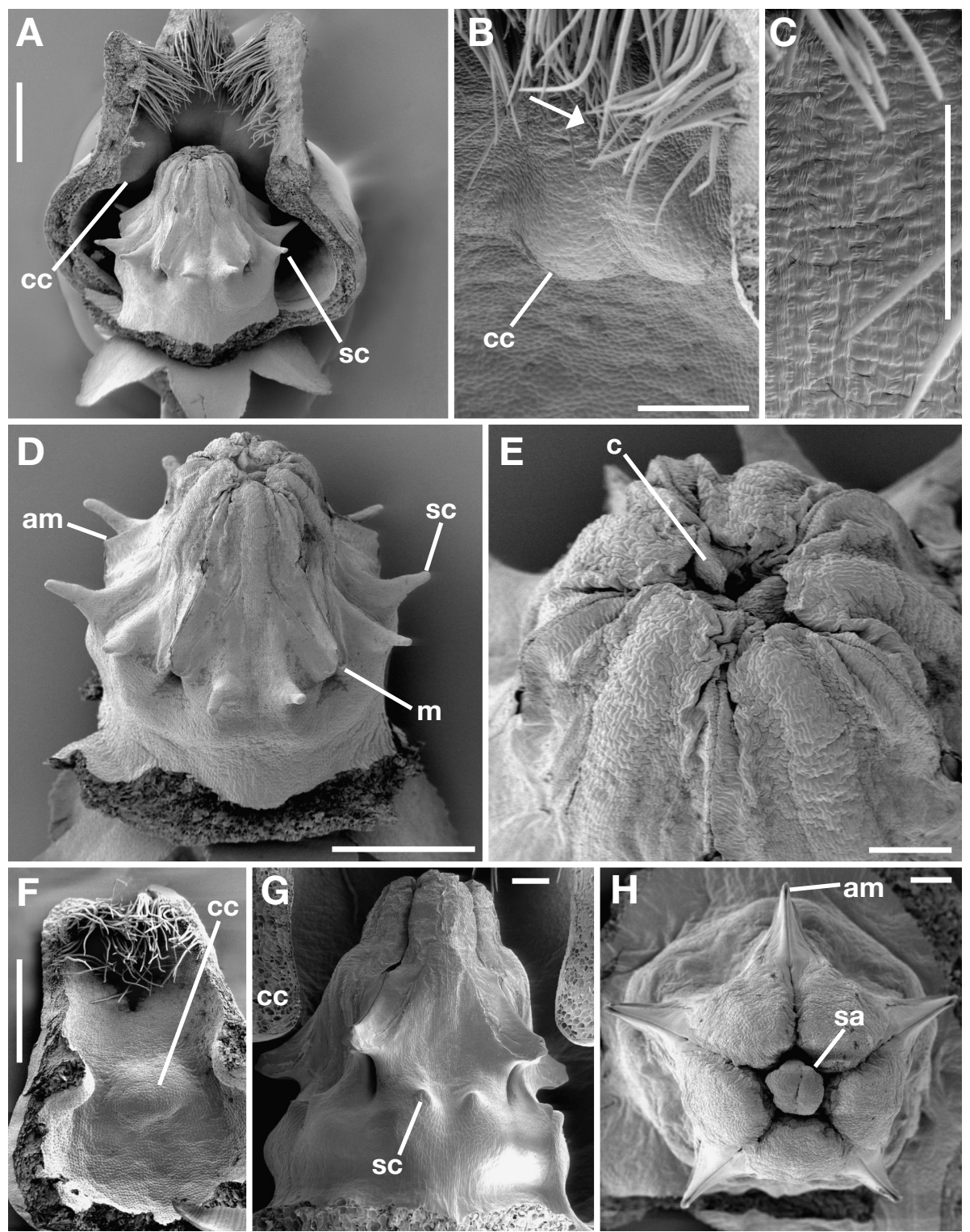

Fig. 3. A-E. Dischidia cornuta Livsh. A. Flower with half of corolla removed; B. corolline corona lobe; C. flat epidermal cells on adaxial surface of corolla lobes; D. gynostegium; E. apex of gynostegium. - F-H. Dischidia imbricata (Blume) Steud. F. Adaxial side of corolla with corolline corona lobe; G. gynostegium; H. apex of gynostegium (A-E: Livshultz 02-50; F-H: Livshultz 99-7). arrow $=$ sinus between corolla lobes, $\mathrm{am}=$ anther margins, $\mathrm{c}=$ connective appendage, $\mathrm{cc}=$ corolline corona lobe, $\mathrm{m}=$ mouth at base of anther margin, $\mathrm{sa}=$ style-head apex, $\mathrm{sc}=$ staminal corona lobe. - Scale bars: A, D, F = 500 $\mu \mathrm{m} ; \mathrm{B}=200 \mu \mathrm{m} ; \mathrm{C}, \mathrm{E}, \mathrm{G}, \mathrm{H}=100 \mu \mathrm{m}$. 
the gynostegium visible when flower viewed from above (not apparent in herbarium specimens). Adaxial epidermal cells except hair cells with flat anticlinal walls. Corolline corona consisting of 5 low, cordate lobes, 0.3 by $0.4 \mathrm{~mm}$ inserted in the corolla lobe sinuses (very obscure in herbarium specimens). Gynostegium 1-1.2 by $0.9 \mathrm{~mm}$, conic in outline, stipitate. Stipe $0.3 \mathrm{~mm}$ tall, glabrous, pale yellow. Anthers triangular $0.7-0.8$ by $0.5 \mathrm{~mm}$, connectives reddish with triangular, white, hyaline appendages, c. 150 by $150 \mu \mathrm{m}$, covering the style-head apex, thecae white, anther margins with a very narrow mouth at the base. Staminal corona lobes each of 2 straight arms, c. 0.2 $\mathrm{mm}$ long, projecting perpendicular to vertical axis of the gynostegium, pale yellow. Sclerenchyma restricted to the anther margins, absent from staminal corona lobes. Pollinarium with pollinia acropetal to the corpuscle in situ. Corpuscle elliptic 190-200 by $60 \mu \mathrm{m}$, apex obtuse, rounded to truncate. Caudicles $240-250$ by $130-140 \mu \mathrm{m}$ at the widest dimension (at level of pollinium attachment), triangular, flattened, with a prominently thickened region along their inner edges and a small wing extending from the outer edges. Pollinium subterete, obovoid, 330-340 by $160-190 \mu \mathrm{m}$ wide. Carpels 1.2 by $0.6 \mathrm{~mm}$, obclavate, half terete, glabrous, green. Style-head radially five angled, obnapiform, 0.7 by $0.6 \mathrm{~mm}$ (including apex), green; apex 0.3 by $0.15 \mathrm{~mm}$ diam. at base, capitate, yellow, completely hidden by the anther connectives. Fruit 1 or follicles developing from each flower, pedicels $2.5-4$ by c. $1 \mathrm{~mm}$, follicles 3.7-4.9 by $0.65-0.8 \mathrm{~cm}$ diam., anguste ovate, apex obtuse, base rounded, half-terete to cordate in cross section, glabrous, glaucous, green with splotches of purple, turning tan when ripe, reflexed, forming an $90^{\circ}$ or less angle with the pedicel. Seeds attached to a white, papery placenta, $2-3$ by $0.7-1 \mathrm{~mm}$ diam., compressed-ovoid, obscurely winged on the margin, tan, testa smooth to sparsely papillate, glabrous; coma white.

Distribution - Known from southern Laos.

Habitat - Collected at 400-1000 m elevation.

Etymology - The specific epithet refers to the horn-like appearance of the staminal corona lobes.

Comments - Dischidia cornuta is obviously closely related to the widespread D. imbricata (Blume) Steud. (illustrated in Rintz, 1980), the only other shell-leaved species that occurs in Indochina. Both species lack calycine colleters, and have corollas of similar dimensions and colour with retrorse hairs on the lobe tips and flat adaxial epidermal cells. Dischidia cornuta and D. imbricata look identical without careful examination of the flowers (Table 2). The prominent staminal corona of $D$. cornuta (Fig. 3A, D) easily distinguishes it from $D$. imbricata which has a highly reduced staminal corona (Fig. 3G) that is often not evident in dried specimens. The corolline corona lobes of $D$. cornuta (Fig. 3B) are much less prominent than those of D. imbricata (Fig. 3F) and differ in shape (cordate vs ovoid). On herbarium sheets, D. cornuta appears to lack a corolline corona while that of $D$. imbricata is obvious. The shape of the anther margins is a somewhat subtle character but usually well preserved in herbarium specimens if the flowers are not too distorted by flattening. The anther margins of $D$. imbricata (Fig. 3G) project out prominently at their bases from the gynostegium, while those of D. cornuta (Fig. 3A, D) do not. Additional characters are visible in living or alcohol preserved flowers but obscured in herbarium specimens. The corolla lobes of $D$. cornuta are widely divergent and the gynostegium is visible when the flower is viewed from above (Fig. 2E); in D. imbricata the corolla lobes are slightly reflexed 
Table 2. Comparison of morphological characters of Dischidia cornuta and Dischidia imbricata.

\begin{tabular}{|c|c|c|}
\hline & D. cornuta & D. imbricata \\
\hline corolla throat at anthesis & $\begin{array}{l}\text { wide open, gynostegium } \\
\text { visible from above }\end{array}$ & $\begin{array}{l}\text { almost closed, gynostegium } \\
\text { hidden by hairs }\end{array}$ \\
\hline corolline corona lobes & cordate, not prominent & ovoidal, very prominent \\
\hline staminal corona lobes & prominent, with long arms & obscure, with minute arms \\
\hline base of anther margins & in close proximity to gynostegium & projecting out from gynostegium \\
\hline style-head apex & $\begin{array}{l}\text { covered by anther connective } \\
\text { appendages }\end{array}$ & $\begin{array}{l}\text { exposed, anther connective } \\
\text { appendages tucked around it }\end{array}$ \\
\hline
\end{tabular}

but held close together at anthesis and the gynostegium is completely hidden from view by the retrorse hairs. The anther connective appendages of $D$. cornuta cover the style-head apex (Fig. 2E, 3E) while those of D. imbricata do not (Fig. 3H). Unlike $D$. dohtii, this character is often not apparent in herbarium specimens because the anthers of $D$. imbricata equal the style-head in height. Given that $D$. imbricata occurs in Thailand and Vietnam, sterile specimens from Indochina cannot be identified until the range and habitat of $D$. cornuta are better known.

Additional specimens:

Poilane 12136 (P), Laos, Chipon River, 400 m, 22 July 1925. Livshultz 03-11 (BH), cultivated, field data: Laos, Champasak Province, Ban Thongset, Nong Khoum Khiaou, 15.20 N, 106.32 E, 1000 m, 5 Mar. 2003. Livshultz 03-40 (BH), cultivated, field data: Laos, Champasak Province, Ban Thongset, Nong Khoum Khiaou, 15.20 N, 106.32 E, 1000 m, 7 Sept. 2003.

\section{Dischidia dohtii Tran \& Livsh., spec. nov. - Fig. 4, 5}

Dischidia parvifoliae Ridl. affinis, sed foliis cordatis vel orbicularibus, indumento tenuiter lanato, et absentia appedicum staminalium basalium differens. - Typus: Averyanov et al. 5197 (holo HN; iso A, MO), Vietnam, Kon Tum Province, Kon Plong District, Hieu Municipality, Mang La forest enterprise; primary evergreen broad-leaved wet forest with Dacrycarpus imbricatus on steep mountain slopes on sandstone and gneiss. Creeping epiphyte on high trees, Not common. 14.65 N, 108.42 E, 1100-1200 m, 14 April 2000.

Plants succulent, herbaceous, epiphytes, non-twining root-climbers forming mats on tree branches. Roots on mature plants adventitious, first roots always paired below each node, each root emerging opposite a leaf, within 2 elongated internodes on a actively growing shoot, additional roots produced along internodes. Latex white. Indumentum on all parts of plant except 3 inner floral whorls and roots sparsely lanate with simple, multiseriate (up to 8-celled), white hairs, 400-900 $\mu \mathrm{m}$ long, pubescence sparser on older parts, inflorescence bracts, pedicels, and calyces. Wax chimneys on stems and leaves absent. Stems terete, up to $1 \mathrm{~mm}$ diam.; internodes $0.8-1.3 \mathrm{~cm}$ long. Stipular colleters paired, triangular or ovate, to $0.3 \mathrm{~mm}$ long, inserted on either side of the petiole. Leaves always opposite, decussate early in development, becoming distichous, reddish when young becoming green at maturity except for small purple areas around colleters; petiole $1-1.5$ by $0.4-0.5 \mathrm{~mm}$, inserted on the leaf margin or slightly abaxially; mature lamina $0.5-1.3$ by $0.5-1.5 \mathrm{~cm}$, very succulent, biconvex, maximum thickness 0.6 $\mathrm{cm}$ (wrinkled in herbarium specimens), orbicular to compressed ovate, base rounded, truncate, to slightly cordate, bearing one triangular colleter, c. $0.1 \mathrm{~mm}$ long, on the 


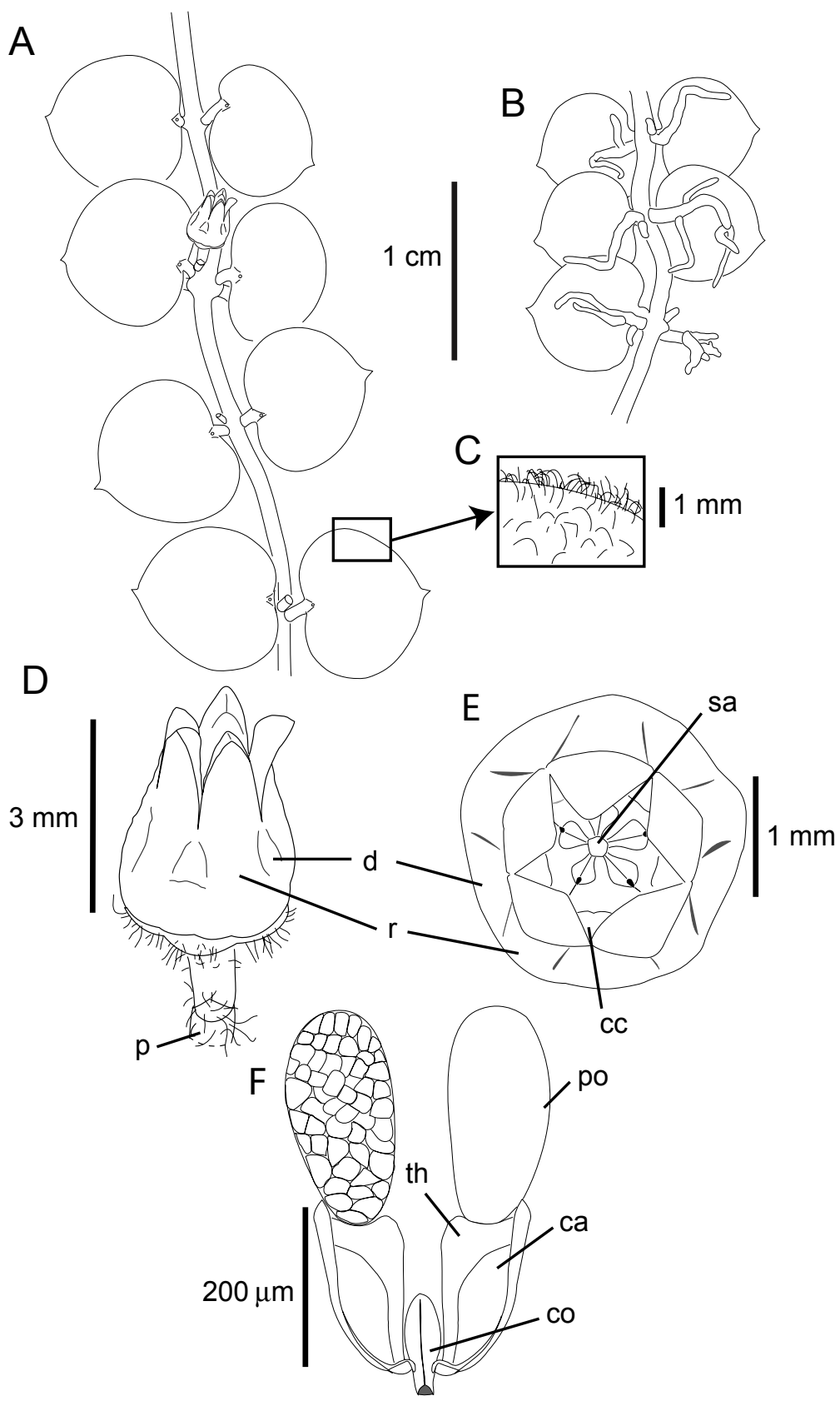

Fig. 4. Dischidia dohtii Tran \& Livsh. A. Flowering shoot, upper side; B. shoot, underside with roots; C. lanate pubescence; D. inflorescence with single flower; E. flower viewed from above; F. pollinarium (A-E: Livshultz 02-53; F: Averyanov et al. 5197). $\mathrm{ca}=$ caudicle, $\mathrm{cc}=$ top of corolline corona lobe, $\mathrm{co}=$ corpuscle, $\mathrm{d}=$ depression on outer surface of corolla tube, $\mathrm{p}=$ peduncle, $\mathrm{po}=$ pollinium, $r=$ rib along corolla tube below corolla lobe, $s a=$ style-head apex, th $=$ thickened part of caudicle. Drawn by D. Schott and T. Livshultz. 

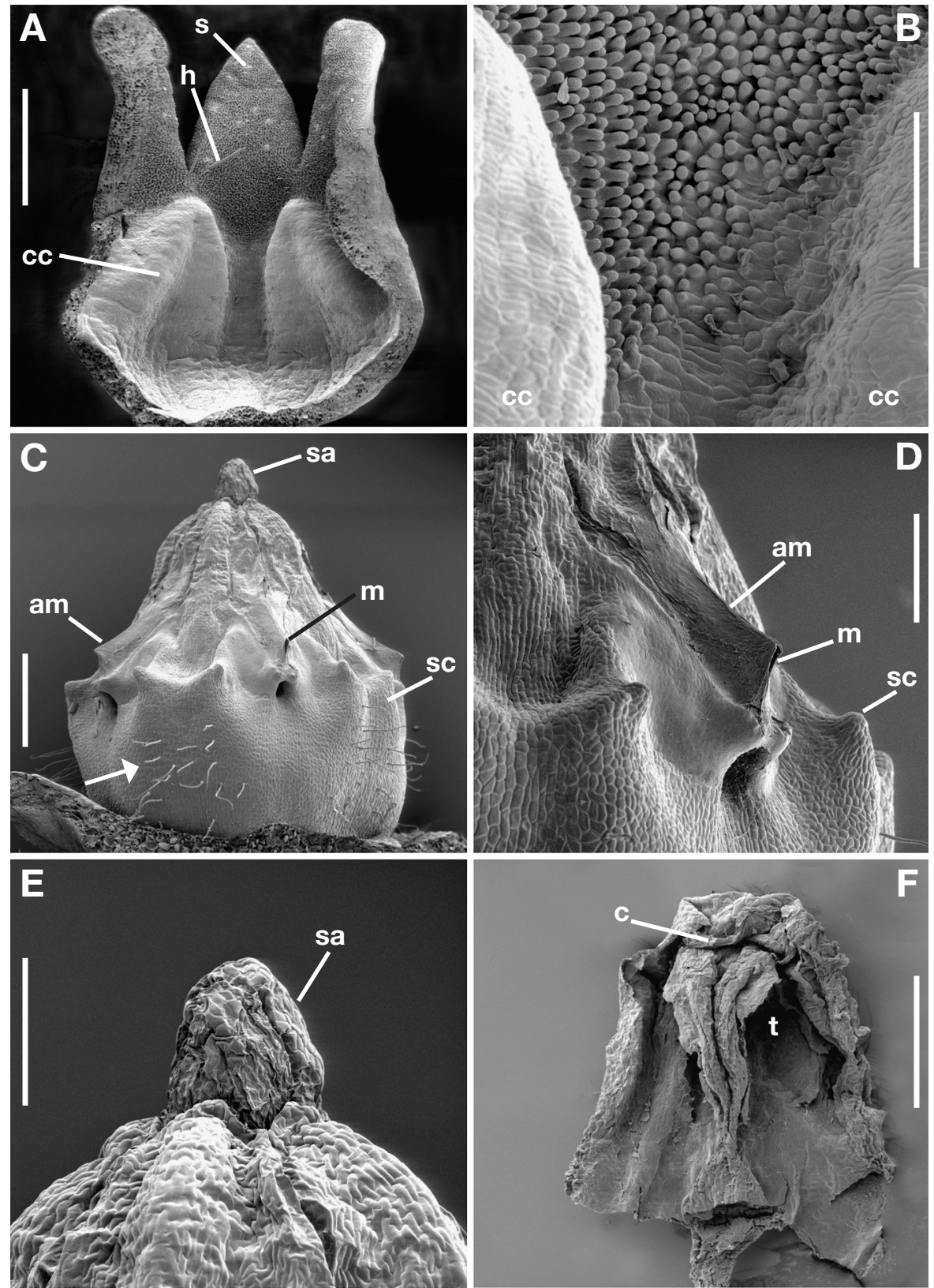

Fig. 5. Dischidia dohtii Tran \& Livsh. A. Adaxial corolla surface; B. adaxial corolla surface closeup, papillate cells distally, flat cells proximally and on the corolline corona lobes; C. gynostegium; D. close up of anther margins and corona; E. close up of exposed style-head apex; F. anther viewed from adaxial side with folded over connective appendage (all: Livshultz 02-53). arrow = hairs on base of gynostegium, $\mathrm{a}=$ anther, $\mathrm{am}=$ anther margins, $\mathrm{c}=$ connective appendage, $\mathrm{cc}=$ corolline corona lobe, $\mathrm{h}=$ hair, $\mathrm{m}=$ mouth at base of anther margins, $\mathrm{s}=$ stomate, $\mathrm{sa}=$ style-head apex, $\mathrm{sc}=$ staminal corona lobe, $\mathrm{t}=$ thecum. - Scale bars: $\mathrm{A}, \mathrm{C}=250 \mu \mathrm{m} ; \mathrm{B}, \mathrm{D}-\mathrm{F}=100 \mu \mathrm{m}$. 
adaxial side at the base of the midrib, apex apiculate (acute), secondary venation not visible. Inflorescence extra-axillary, peduncles $<1-2$ by $1 \mathrm{~mm}$, sparsely lanate, 1 - or 2-flowered. Flowers each subtended by two bracts, bracts c. 0.5 by $0.5 \mathrm{~mm}$, ovate to triangular, sparsely lanate, membranous (chartaceous in dried specimens). Pedicels 1.5 by $0.8 \mathrm{~mm}$, glabrous to pubescent. Calyx lobes quincuncial in bud, 0.5 by $0.5 \mathrm{~mm}$, ovate, apex obtuse, green with hyaline margins, sparsely lanate, bearing a colleter inside each lobe sinus, colleters ovate (cylindroid), $120-150(-450)$ by $90-110(-150)$ $\mu \mathrm{m}$. Corolla succulent, urceolate, 3 by $2-2.5 \mathrm{~mm}$ at widest diameter, widest $0.5 \mathrm{~mm}$ from the base, 5-ribbed, with triangular depressions opposite the sinuses (not evident in dried specimens), tube pale yellowish to off-white, lobes reddish in young buds fading to very pale peach-pink or off-white on the abaxial surface at anthesis, adaxial corolla surface pure white; corolla lobes valvate in bud, reflexed at anthesis, 0.7 by 0.4-0.5 mm, triangular, succulent, with slightly cucullate tips, with small, stomatebearing papillae on the abaxial surface, adaxial surface also with scattered stomates, glabrous or with sparse scattered hairs on the lower part of the corolla lobes and at the throat; throat c. $1 \mathrm{~mm}$ diam., the gynostegium visible when flower is viewed from above. Adaxial epidermal cells uniformly papillate (except for stomatal complexes) on the corolla lobes, papillate cells extending on to the upper portion of the corolla tube opposite the corolla lobe, cells of the corolline corona lobes and lower portion of the corolla tube with flat anticlinal walls. Corolline corona consisting of 5 prominent chevron-shaped wedges, each 0.7 by $0.5 \mathrm{~mm}$, inserted adaxially in the sinuses of the corolla lobes. Gynostegium 1.5 by $1.2 \mathrm{~mm}$, conic in outline, stipitate. Stipe $0.6 \mathrm{~mm}$ long (measurement from insertion on corolla tube to opening below anther margins), white, bearing long hairs on the zone below each staminal corona lobe. Anthers triangular, 0.9 by $0.6 \mathrm{~mm}$, yellow with a longitudinal red stripe on each thecum, apical connective appendages 100 by $250 \mu \mathrm{m}$, ovate, hyaline, held folded over the thecae, tucked around the style-head apex, not covering its tip, adjacent anther margins forming a very narrow mouth at the base. Staminal corona of five, unstalked lobes inserted at the bases of the anthers, each lobe with two minute arms, and a retuse apex, white, without sclerenchyma (staminal corona often appearing as absent in pressed, dried specimens). Sclerenchyma restricted to the anther margins. Pollinarium with pollinia acropetal to the corpuscle in situ. Corpuscle elliptic 130-150 by 40-50 $\mu \mathrm{m}$ wide, apex obtuse, rounded to truncate. Caudicles 240 by $70-90 \mu \mathrm{m}$ at the widest dimension (at level of pollinium attachment), triangular, flattened, with a prominently thickened region along their inner edges and a small wing extending from the outer edges. Pollinium dorsiventrally flattened, elliptic, apex obtuse, $250-290$ by $90-100 \mu \mathrm{m}$. Carpels 0.9 by $0.5 \mathrm{~mm}$, obclavate, half terete, glabrous, green. Style-head radially five angled, obnapiform, 0.7 by $0.6 \mathrm{~mm}$ (including apex), yellow, apex cylindrical, 0.3 by $0.15 \mathrm{~mm}$, its distal half purple, projecting above the anthers. Fruit unknown.

Distribution - Collected from southern Laos and central Vietnam.

Habitat - 1000-1200 m elevation.

Etymology - Dischidia dohtii (dōtē̄i) is named after Doth Laounmuang, director of Project Green Life, an education and conservation initiative working to protect the forest at Nong Khoum Khiaou in Champasak Province, Laos. The transliteration of Mr. Laounmuang's name has been modified to facilitate correct pronunciation of the species epithet by English speakers. 
Comments - Of other species in Vietnam and Laos, $D$. dohtii is most likely to be confused with $D$. nummularia R. Br. (illustrated in Rintz, 1980). The two species have the same creeping, non-twining growth habit, similar succulent, apiculate, orbicular leaves, short, few-flowered peduncles, and small whitish flowers. The two species can easily be distinguished by characteristics of the vegetative epidermis which is sparse lanate, without wax chimneys in $D$. dohtii and glabrous, with wax chimneys in $D$. nummularia. A few herbarium specimens of $D$. nummularia lack wax chimneys, probably due to artefacts of preservation such as flaking off of the epicuticular wax or coating of the specimen with glue, or possibly collection of very young or mesic branches. Such specimens can still be distinguished from $D$. dohtii by their lack of pubescence and by floral characters. The most obvious floral character is the reduced (often appearing as absent in herbarium specimens) staminal corona of $D$. dohtii vs the prominent stalked, anchor-shaped corona lobes of $D$. nummularia (illustrated in Rintz, 1980). The exposed style-head apex of $D$. dohtii and the covered style-head apex of D. nummularia are also reliably preserved on herbarium specimens. Habitat is also a good clue, since $D$. nummularia is consistently a lowland species while $D$. dohtii appears to be restricted to highland areas. The two species are compared in Table 3. The very long, cylindroid calycine colleters found in some flowers of $D$. dohtii are very distinctive but they cannot be considered a species character since they are only rarely present. The absence of condensed, bracteate inflorescence axes on our specimens also should not be considered as a species character. These axes develop with successive cycles of flowering, and given that $D$. dohtii only produces 1 or 2 flowers at a time, may take a long time to develop in this species.

In spite of the superficial similarity of $D$. dohtii to $D$. nummularia, D. dohtii is probably more closely related to $D$. parvifolia Ridl., a highland endemic from Peninsular

Table 3. Comparison of morphological characters of Dischidia dohtii with Dischidia parvifolia, Dischidia nummularia, and Dischidia khasiana.

\begin{tabular}{|c|c|c|c|c|}
\hline & D. dohtii & D. parvifolia & D. nummularia & D. khasiana \\
\hline $\begin{array}{l}\text { wax chimneys on } \\
\text { leaves and stems }\end{array}$ & absent & absent & present (absent) & absent \\
\hline indumentum & sparse lanate & $\begin{array}{l}\text { tomentose-papillate, } \\
\text { glabrescent }\end{array}$ & glabrous & $\begin{array}{l}\text { tomentose-papillate, } \\
\text { glabrescent }\end{array}$ \\
\hline pedicel length (mm) & 1.5 & $2.5-5$ & $1-2$ & 3 (in fruit) \\
\hline $\begin{array}{l}\text { hairs inside } \\
\text { corolla tube }\end{array}$ & $\begin{array}{l}\text { absent or sparse } \\
\text { on bases of } \\
\text { corolla lobes and } \\
\text { at throat }\end{array}$ & absent & $\begin{array}{l}\text { more or less } \\
\text { dense on bases } \\
\text { of corolla lobes }\end{array}$ & unknown \\
\hline $\begin{array}{l}\text { adaxial epidermal cells } \\
\text { of corolla lobes and } \\
\text { distal corolla tube }\end{array}$ & papillate & papillate & flat & unknown \\
\hline $\begin{array}{l}\text { hairs on the } \\
\text { gynostegial stipe }\end{array}$ & present & present & absent & unknown \\
\hline $\begin{array}{l}\text { staminal corona } \\
\text { segment }\end{array}$ & $\begin{array}{l}\text { small lobe with } \\
\text { minute arms, } \\
\text { may appear } \\
\text { as absent }\end{array}$ & $\begin{array}{l}\text { small lobe without } \\
\text { arms, may appear } \\
\text { as absent }\end{array}$ & $\begin{array}{l}\text { prominent, stalked, } \\
\text { anchor-shaped lobe } \\
\text { with well-developed } \\
\text { recurved arms, } \\
\text { always evident }\end{array}$ & unknown \\
\hline
\end{tabular}


Malaysia (illustrated in Rintz, 1980). Both species lack wax chimneys on their vegetative organs, have papillate epidermal cells on the adaxial surface of the corolla lobes, pubescent gynostegial stipes, reduced staminal coronas, and protruding style-head apices that are not hidden by the anther connective appendages (Table 3). Dischidia dohtii can easily be distinguished from $D$. parvifolia by leaf shape and indumentum (orbicular to cordate and lanate vs ovate and tomentose to glabrescent) and pedicel length (1.5 mm vs $2.5-5 \mathrm{~mm}$ ) (Table 3 ). The anthers of $D$. parvifolia have prominent basal appendages, giving them a distinctly sagittate appearance; no such appendages are present in $D$. dohtii.

Additional specimens:

Livshultz 02-53 (BH, National University of Lao), cultivated, field data: Laos, Champasak Province, Ban Thongset, Nong Khoum Khiaou, 15.20 N, 106.32 E, 1000 m, 23 Sept. 2002.

\section{Dischidia khasiana Hook.f. - Fig. 6A, B}

Dischidia khasiana Hook.f. (1885) 50; A.P. Jagtap \& N.P. Singh (1999) 74. - Type: Hooker f. \&

T. Thomson 9 (lecto K, designated here, isolecto A, G, L), India, Megalaya Province, Khasia Mountains at Churra and Nunklow, alt. 3-4000 ft.

Comments - The enigmatic D. khasiana Hook.f., known from a single fruiting collection, might also be related to $D$. dohtii. Both species have small, orbicular, apiculate leaves, no wax chimneys, and unbranched inflorescences with short peduncles. Both occur around $1000 \mathrm{~m}$ elevation. The two species can be differentiated by their

A
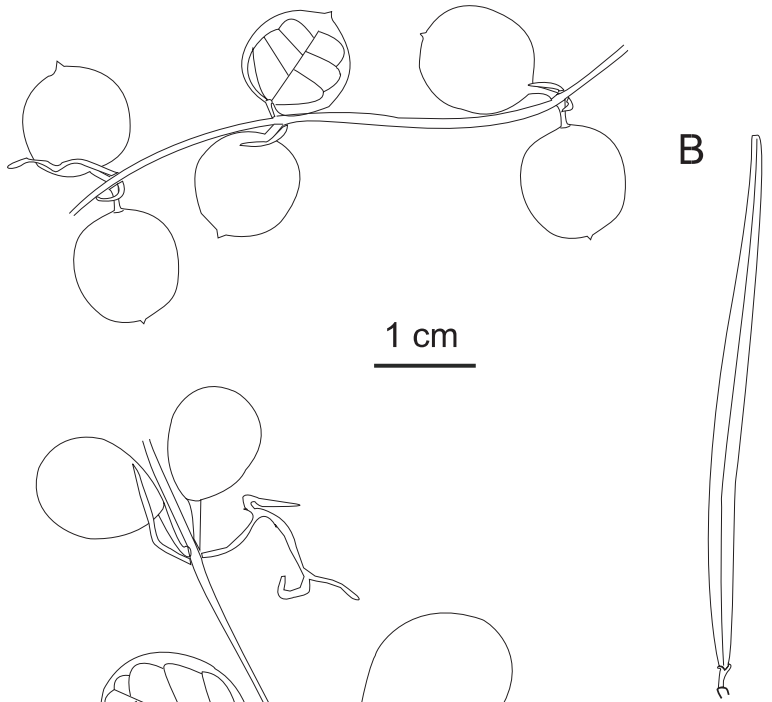

C

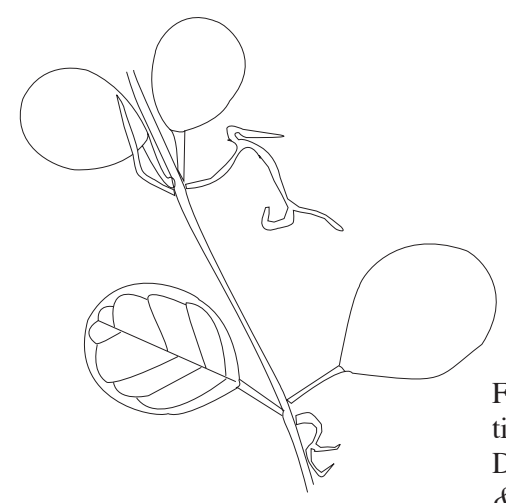

Fig. 6. A, B. Dischidia khasiana Hook.f. A. Vegetative shoot; B. infructescence. - C. Hoya nummularia Decne. ex Hook.f., vegetative shoot (A, B: Hookerf. \& Thomson 9; C: Chatterjee \& Saha 13598). Drawn by T. Livshultz. 
indumentum: sparse lanate, hairs 400-900 $\mu \mathrm{m}$ long, in $D$. dohtii, tomentose to glabrescent, hairs 100-200 $\mu \mathrm{m}$ long, in D. khasiana. The type of D. khasiana is a mixed collection with Hoya nummularia Decne. ex Hook.f. One of the sheets at K is entirely material of Dischidia khasiana while the other is predominantly H. nummularia. The sheets at A, G, and L are predominantly or entirely D. khasiana, while sheets at $\mathrm{M}$ and $\mathrm{C}$ are predominantly or entirely $H$. nummularia. Flowers of $H$. nummularia are present on the sheet from M. Hoya nummularia (Fig. 5C) also has small orbicular leaves, but its leaf apices are obtuse, not apiculate, and its petioles $(3-7 \mathrm{~mm})$, peduncles $(50 \mathrm{~mm}$ long) and pedicels $(20-25 \mathrm{~mm})$ are much longer than those of $D$. khasiana (petioles $1-2(-3) \mathrm{mm}$, peduncles $1 \mathrm{~mm}$, pedicels $3 \mathrm{~mm}$ ).

Dischidia khasiana Hook.f. is here lectotypified by the sheet deposited at K, annotated by the senior author, that does not contain any material of $H$. nummularia.

\section{Dischidia rimicola Kerr - Fig. 7, 8}

Dischidia rimicola Kerr (1939) 463; Craib \& Kerr (1951) 47. - Type: Put 2984 (K), Thailand, Krat, Kao Kuap, 24 May 1930.

Plants succulent, herbaceous, epiphytic vines, with a tendency to grow from a single root stock rather than to cling by adventitious roots, pendulous and twining. Roots on mature plants adventitious, first roots paired or solitary, each root initiated in a leaf axile, 5-10 elongate internodes below the apex of an actively growing stem, additional adventitious roots frequently produced near each node and along the internodes. Latex white. Indumentum tomentose, hairs curling, simple, uniseriate, 0.1-0.2 $\mathrm{mm}$ long on all parts except the inner three floral whorls and roots, hairs sparser (rarely absent) on older stems, limited to near the margins and petioles of mature leaves. Wax chimneys absent. Stems terete; 1-2 mm diam.; internodes 1.5-9.5 cm long. Stipular colleters paired, triangular or ovate, to $0.1 \mathrm{~mm}$ long, inserted on either side of each petiole. Leaves always opposite, decussate early in development, becoming distichous; petiole 1-3.5 by $0.8-1 \mathrm{~mm}$, inserted on blade margin; blade $1.7-3$ by $0.8-1.3 \mathrm{~cm}$, ovate or elliptic, apex acute to acuminate, base cuneate to rounded, with slightly involute margins in younger leaves, plano (adaxial-)convex (abaxial) in older leaves, 1-3 mm thick, bearing a single ovate colleter c. $0.1 \mathrm{~mm}$ long at the base of the adaxial surface; venation obscure in living plants, prominent in herbarium specimens, brochidodromous with $2-5$ secondaries on each side of the midrib. Inflorescence extra-axillary, umbelliform, persistent through many flowering cycles, sessile, a single, condensed axis bearing 3-7 flowers and buds at various stages of maturity, 1 or 2 flowers simultaneously at anthesis; lower portions of axis bearing scars and bracts from fallen flowers. Flowers subtended by two membranous triangular to lunate, glabrous to sparse pubescent bracts, c. 0.5 by $0.5 \mathrm{~mm}$, the bracts becoming chartaceous, persistent after flowers fall, but wearing off from the oldest parts of the rachis. Pedicels $1.5-2$ by $0.5 \mathrm{~mm}$, pale green, glabrous or sparse pubescent. Calyx lobes quincuncial in bud, $0.6-0.7$ by $0.5-0.6 \mathrm{~mm}$, triangular to ovate, apex obtuse to acute, sparsely pubescent abaxially, pale green sometimes with purple pigment on the tips, with hyaline margins, margins ciliate or not, with a single minute colleter inside each sinus. Corolla succulent, full of nectar, urceolate, 3.5-4 by $2.5 \mathrm{~mm}$ at widest diameter, widest c. $0.5 \mathrm{~mm}$ from the base, 5-lobed at base, lobes opposite the sepals, abaxially with stomate bearing papillae, corolla cream-white with 

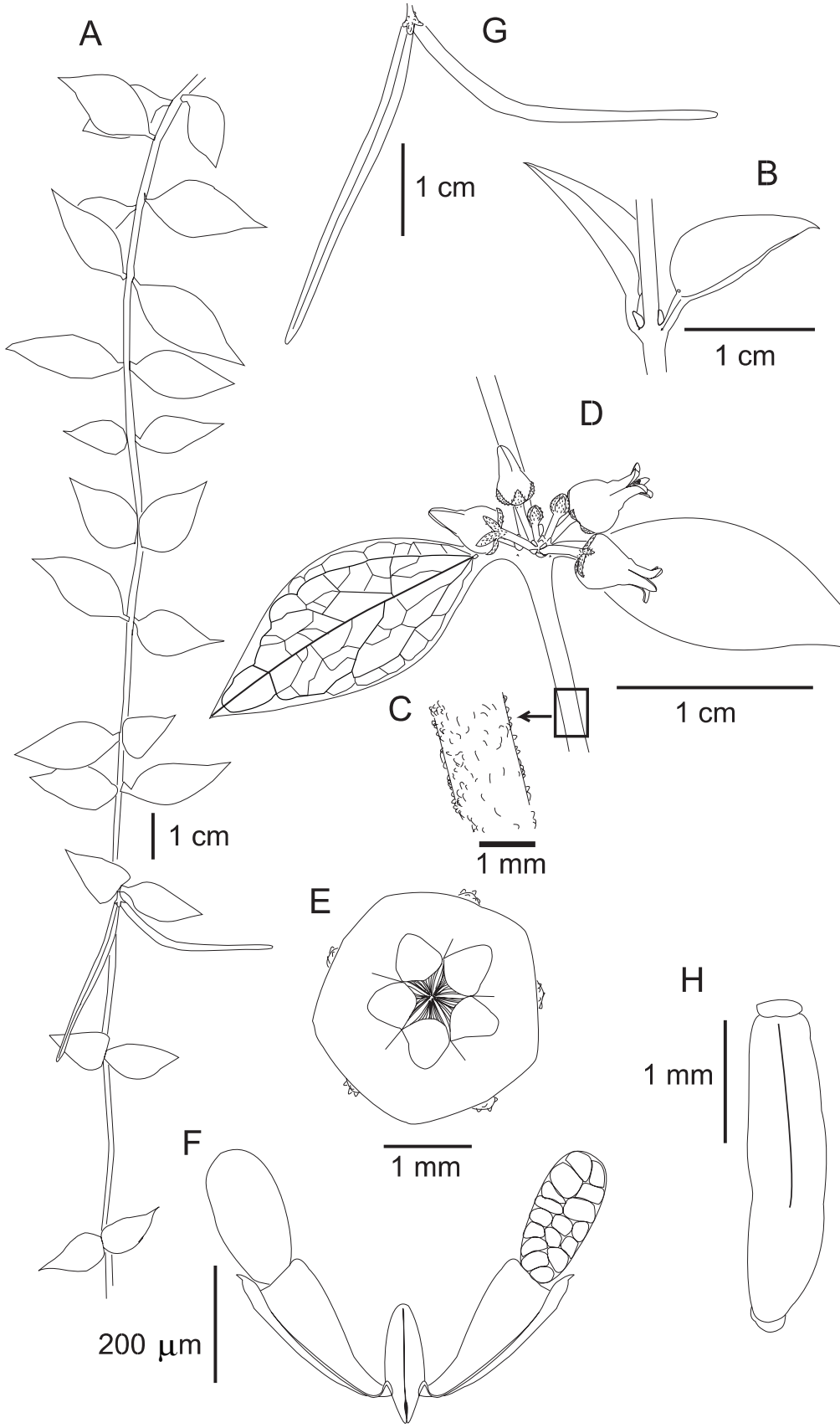

Fig. 7. Dischidia rimicola Kerr. A. Fruiting shoot; B. node with first adventitious roots initiated in the leaf axils; C. tomentose pubescence on stem; D. node with inflorescence; E. flower at anthesis viewed from above; F. pollinarium, slight thickening of caudicle not depicted because it is not visible with light microscopy; G. fruit; H. seed without coma (A, G: drawn from photo, population vouchered by Livshultz 01-24; B-F: Livshultz 01-24; H: Poilane 28421). Drawn by T. Livshultz. 

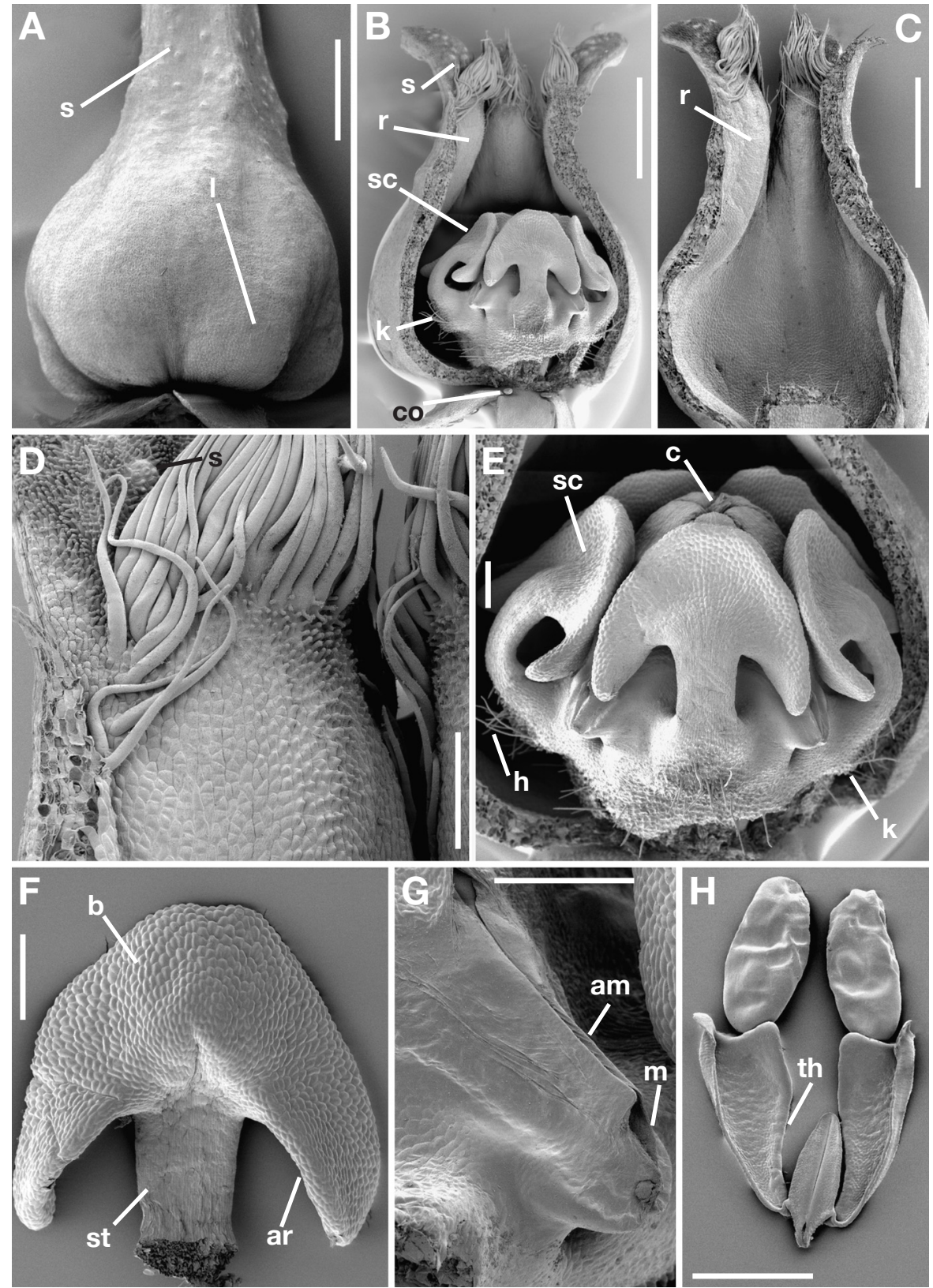

Fig. 8. Dischidia rimicola Kerr. A. Base of corolla tube of bud near anthesis; B. flower with 2 petals removed; C. adaxial side of corolla; D. adaxial surface of corolla lobe; E. gynostegium; F. adaxial surface of staminal corona lobe; G. anther margins; H. pollinarium (all: Livshultz 01-24). am = anther margins, $\mathrm{ar}=\mathrm{arm}, \mathrm{b}=$ blade, $\mathrm{c}=$ connective appendage, $\mathrm{co}=$ colleter, $\mathrm{h}=$ hair, $\mathrm{k}=\mathrm{knob}$ at base of staminal corona lobe, $1=$ basal lobe of corolla tube, $\mathrm{m}=$ mouth at base of anther margins, $\mathrm{r}=\mathrm{rib}, \mathrm{s}=$ stomate, $\mathrm{sc}=$ staminal corona lobe, $\mathrm{st}=$ stalk, th $=$ thickening of inner margin of caudicle. - Scale bars: $\mathrm{A}=200 \mu \mathrm{m} ; \mathrm{B}, \mathrm{C}=500 \mu \mathrm{m} ; \mathrm{D}-\mathrm{H}=100 \mu \mathrm{m}$. 
or without purple pigment on adaxial or abaxial surface of the corolla lobe tips. Corolla lobes valvate in bud, $1.5-1.8$ by $0.7-1 \mathrm{~mm}$, triangular, each with a low rounded rib adaxially that extends into upper part of the tube, tips only slightly thickened adaxially, at anthesis remaining connivent along their margins for c. $50 \%$ of their length, diverging distally, each bearing a wedge of long, straight, antrorse hairs near its centre, wedges forming a cone of hairs closing the corolla throat and hiding the gynostegium. Adaxial epidermal cells (except stomatal complexes) papillate above the hairs, flat below them except for a few papillate cells along the midline of the rib. Corolline corona absent. Gynostegium $1.2-1.4 \mathrm{~m}$ by c. $1.2 \mathrm{~mm}$, conic in outline, stipitate. Stipe c. $0.4 \mathrm{~mm}$ tall (measurement from insertion on corolla tube to opening below anther margins), pubescent with tufts of hairs below each staminal corona lobe. Anthers triangular $0.8-1$ by $0.8-1 \mathrm{~mm}$; connectives purple with triangular, white, hyaline appendages covering the style-head apex; thecae white; anther margins forming an elliptic mouth at their base. Staminal corona of five white, membranous lobes inserted at the bases of the anthers, each lobe with a small, pubescent knob at its base, stalked with sagittate apex, stalk 200 by $100 \mu \mathrm{m}$, apex 250 by $450 \mu \mathrm{m}$, concave abaxially, convex adaxially, with obtuse, entire apical margin, arms falcate, $150 \mu \mathrm{m}$ long. Sclerenchyma restricted to the anther margins, and along the margins of the staminal corona lobe apex. Pollinarium with pollinia acropetal to the corpuscle in situ. Corpuscle elliptic $200-210$ by $70 \mu \mathrm{m}$, apex obtuse, rounded to truncate. Caudicles $310-330$ by $100-120 \mu \mathrm{m}$ at the widest dimension (at level of pollinium attachment), triangular, flattened, with very slightly thickened regions along their inner edges (not evident with light microscopy) and small wings extending from the outer edges. Pollinium elliptic, compressed, 240-260 by $110-130 \mu \mathrm{m}$. Carpels 0.7 by $0.4 \mathrm{~mm}$, obclavate, half-terete. Style-head radially 5-angled, turbinate, $0.4-0.5$ by $0.6-0.7 \mathrm{~mm}$ (including apex), pale yellow, apex a small papilla, c. $0.1 \mathrm{~mm}$ tall, pale yellow. Fruit 1 or 2 follicles developing from each flower, pedicels $2-2.5$ by c. $1 \mathrm{~mm}$, follicles $4-5$ by $0.2 \mathrm{~cm}$ diam., linear, glabrous, green turning tan when ripe, forming a $120-180^{\circ}$ angle with the pedicel. Seeds attached to a white, papery placenta, $2.5-2.7$ by $0.5-0.6 \mathrm{~mm}$ diam., ellipsoid, terete to subterete, wing restricted to chalazal end, testa papillate, glabrous, tan; coma white.

Distribution - Known from Thailand, Laos, and Vietnam, may also occur in Cambodia.

Habitat - All collections of D. rimicola are from elevations at or above $1000 \mathrm{~m}$.

Comments - Dischidia rimicola belongs to a potentially monophyletic group of species distinguished by long, narrow, basally connivent, distally reflexed corolla lobes with antrorse hairs on the middle of the lobe, no corolline corona, and stalked staminal corona lobes with sagittate apices. This group also includes $D$. formosana Maxim. from Taiwan (illustrated in Lu \& Kao, 1978), D. scortechinii King \& Gamble from Malaysia (illustrated in Rintz, 1980), D. singularis Craib and D. tricholoba Kerr from Indochina (Table 4). Dischidia singularis has cross-shaped leaves with two lateral lobes and is impossible to mistake for any other species. Dischidia tricholoba has ovate to elliptic leaves and is more likely to be mistaken for D. rimicola, especially Vietnamese specimens which have markedly smaller leaves than Thai plants, $1.2-2.3 \mathrm{vs} 3.5-7 \mathrm{~cm}$ long. Dischidia tricholoba can be reliably distinguished from $D$. rimicola by its usually glabrous stems and calyces, larger flowers ( 5 vs 3.5-4 mm), absence of ribs on the adaxial sides of the corolla lobes, and absence of hairs on the gynostegial stipe (Table 4). 
Table 4. Comparison of morphological characters of Dischidia rimicola, Dischidia singularis, and Dischidia tricholoba.

\begin{tabular}{|c|c|c|c|}
\hline & D. rimicola & D. singularis & D. tricholoba \\
\hline $\begin{array}{l}\text { mature leaf lamina } \\
\text { length by width }(\mathrm{cm}) \\
\text { and shape }\end{array}$ & $\begin{array}{l}1.7-3 \text { by } 0.8-1.3 \\
\text { elliptic, ovate, apex acute- } \\
\text { acuminate, base cuneate } \\
\text { to rounded }\end{array}$ & $\begin{array}{l}3.5-5.5 \text { by } 0.7-0.8 \\
\text { cross-shaped with } \\
2 \text { lateral lobes, apex } \\
\text { acute-apiculate, base } \\
\text { cuneate to rounded }\end{array}$ & $\begin{array}{l}1.2-7 \text { by } 0.5-3 \\
\text { ovate, elliptic, apex } \\
\text { acute, base rounded } \\
\text { to cuneate }\end{array}$ \\
\hline stem indumentum & tomentose, glabrescent & $\begin{array}{l}\text { glabrous (sparse } \\
\text { pubescent) }\end{array}$ & $\begin{array}{l}\text { glabrous (sparse } \\
\text { pubescent) }\end{array}$ \\
\hline calyx indumentum & tomentose & glabrous & $\begin{array}{l}\text { glabrous (very sparse } \\
\text { pubescent) }\end{array}$ \\
\hline $\begin{array}{l}\text { corolla length by dia- } \\
\text { meter (mm) (hydrated) }\end{array}$ & $3.5-4$ by 2.5 & $3-3.5$ by 2 & 5 by $2-2.5$ \\
\hline $\begin{array}{l}\text { ribs on adaxial side of } \\
\text { corolla lobes }\end{array}$ & present & absent & absent \\
\hline $\begin{array}{l}\text { hairs on gynostegial } \\
\text { stipe }\end{array}$ & $\begin{array}{l}\text { prominent tuft below } \\
\text { staminal corona lobe }\end{array}$ & absent (minute pubescent) & absent \\
\hline staminal corona lobe & $\begin{array}{l}\text { stalked, apex sagittate } \\
\text { with prominent arms }\end{array}$ & $\begin{array}{l}\text { stalked, apex semi-lunate } \\
\text { with very reduced arms }\end{array}$ & $\begin{array}{l}\text { stalked, apex sagittate } \\
\text { with prominent arms }\end{array}$ \\
\hline
\end{tabular}

It is possible that $D$. tricholoba is not a distinct species but only the juvenile growth form of $D$. singularis. Dischidia singularis was described as having dimorphic juvenile and adult foliage (Craib \& Kerr, 1951), and specimens identified as the juvenile form of $D$. singularis match the type of D. tricholoba (Kerr 7775, K). Plants with both morphologies are sympatric in Thailand, but we have not seen any specimens with both types of foliage on the same plant. Dischidia tricholoba and D. singularis differ not only in leaf shape but also in flower size and staminal corona lobe shape (Table 4). We will recognize $D$. singularis and $D$. tricholoba as distinct species until we see evidence to the contrary.

\section{ACKNOWLEDGEMENTS}

Tatyana Livshultz, Daniel Schott, and Somchanh Bounphanmy are grateful for the assistance of Mme. Buakhaykhone Svengsuksa of the National University of Lao, and Doth Laounmuang, Kampong and Hubert Bahler of Project Green Life. We thank the curators of A, BH, BISH, BKF, BRIT, C, CAL, F, G, HN, K, KEP, L, M, MO, NY, P, PH, PNH, SING, UKM, and US for the use of specimens. We thank Roberto Keller for identifying our ant specimens to morphospecies, William Dress for translation of the diagnoses into Latin, and Melissa Luckow, Dom Paolillo, Jeff Doyle, F. Adema and one anonymous reviewer for their comments. Funding for this research was provided by the Mario Einaudi Foundation, the Explorers' Club, and NSF dissertation improvement grant \#DEB-9902073 to Tatyana Livshultz.

\section{REFERENCES}

Craib, W.G. \& A.F.G. Kerr. 1951. Asclepiadaceae. In: W.G. Craib, Flora Siamensis enumeratio 3: 1-51. Bangkok Times Press, Bangkok.

Forster, P.I., D. J. Liddle \& A. Nicholas. 1996. Asclepiadaceae. In: R. Robertson et al. (eds.), Flora of Australia 28. Gentianales: 197-283. CSIRO, Melbourne. 
Hooker, J.D. 1885. Asclepiadeae. In: J.D. Hooker, The Flora of British India 4: 1-65. Reeve, London.

Jagtap, A.P. \& N.P. Singh. 1999. Asclepiadaceae. Fascicles of the Flora of India. Fascicle 24. Botanical Survey of India, Calcutta.

Janzen, D.H. 1974. Epiphytic myrmecophytes in Sarawak: mutualism through the feeding of plants by ants. Biotropica 6: 237-259.

Kaufmann, E., A. Weissflog, R. Hashim \& U. Maschwitz. 2001. Ant-gardens on the giant bamboo Gigantochloa scortechinii (Poaceae) in West-Malaysia. Insectes sociaux 48: 125-133.

Kerr, A.F.G. 1939. Contributions to the flora of Siam. Kew Bull. 8: 463-464.

Kleijn, D. \& R. van Donkelaar. 2001. Notes on the taxonomy and ecology of the genus Hoya (Asclepiadaceae) in central Sulawesi. Blumea 46: 457-483.

Li, P. T., M.G. Gilbert \& W.D. Stevens. 1995. Asclepiadaceae. In: Z. Wu \& P.H. Raven (eds.), Flora of China 16. Gentianaceae through Boraginaceae: 189-270. Missouri Botanic Garden, St. Louis.

Livshultz, T. 2003a. Systematics of Dischidia R.Br. (Apocynaceae, Asclepiadoideae). Dissertation. Cornell University.

Livshultz, T. 2003b. Dischidia cleistantha (Apocynaceae, Asclepiadoideae): a new Philippine endemic. Novon 13: 89-96.

Lu, F.Y. \& M.T. Kao.1978. Asclepiadaceae. In: H.L. Li et al. (eds.), Flora of Taiwan 4: 222-246.

Pham-hoang, H. 1993. Cay co Vietnam: An illustrated Flora of Vietnam. Montreal.

Rintz, R.E. 1980. The Peninsular Malayan species of Dischidia (Asclepiadaceae). Blumea 26: 81-126.

Treseder, K.K., D. W. Davidson \& J.R. Ehleringer. 1995. Absorption of ant-provided carbon dioxide and nitrogen by a tropical epiphyte. Nature 375: 137-139.

\section{IDENTIFICATION LIST}

Collections are identified according to the species list below. Unnumbered collections are not included. Collections from institutions are listed under the abbreviation of the institution with the collectors' names in parentheses after the specimen numbers. Components of mixed collections are identified by the abbreviation 'p.p.'.

1. Dischidia acuminata Costantin

2. Dischidia acutifolia Maingay ex. Hook.f.

3. Dischidia bengalensis Colebr.

4. Dischidia cornuta Livsh.

5. Dischidia dohtii Tran \& Livsh.

6. Dischidia formosana Maxim.

7. Dischidia griffithii Griff. ex Hook.f.

8. Dischidia hirsuta (Blume) Decne.

9. Dischidia imbricata (Blume) Steud.

10. Dischidia khasiana Hook.f.
11. Dischidia major (Vahl) Merr.

12. Dischidia nummularia R.Br.

13. Dischidia oiantha Schltr.

14. Dischidia parvifolia Ridl.

15. Dischidia rimicola Kerr

16. Dischidia scortechinii King \& Gamble

17. Dischidia singularis Craib

18. Dischidia tonkinensis Costantin

19. Dischidia tricholoba Kerr

20. Hoya nummularia Decne. ex Hook.f.

Anderson 5110: 8; 9872:11; 30724: 11 - Anonymous 386: 18 - Averyanov et al. 2387: 12; 5197: 5; 5658: 1; 6366: 19.

Bakhuizen van den Brink 2283: 9; 2899: 12; 7817:9 - Balansa 2081:18; 2082: 18 - Beaman 9405a p.p.: 12 - Bember 103: 3- Bien 1416: 9 - Blume 1694: 9 - Boden Kloss see Kloss - Bon 1551: 18; 2537: 1 - Brass 7598:11; 7664: 12; 22004: 11 - BSIP 7873 (Susui): 12 - Burkill 4400: 12 - Burkill \& Holttum 8411: 16- Burkill \& Md. Shah 1026: 8 - Buwalda 6770: 8.

Carr 12215: 8; 12752: 11; 16133: 8 - Charoenpol et al. 4221: 15 - Chatterjee \& Saha 13598: 20 - Chevalier 31796: 12 - Clarke 6598: 12; 27298: 3 - J. \& M.S. Clemens 3489: 8 - Collins 1105: 8; 1232: 17 - Coode \& Katik 40128: 8 - Copeland 512: 12 - Curran 19415 p.p.: 11, p.p.: 13 - Curtis 3554: 12 .

De Haan 1812: 8 - De Vogel 7690: 12 - De Wilde \& De Wilde-Duyfjes 12182:2; 14495: 2; 20524: 9 - Docters van Leeuwen-Reijnvaan 11522: 9; 11984: 12. 
Edaño 35367: 8 - Edwards 4021: 12 - Elmer 9479: 12; 10481: 12; 12952: 8; 13533: 12; 15797: 13; 15798: 12; 15799: 8; 16974: 12 - Evrard 602: 3; 942: 19.

Fenix 28221: 13 - Fukuoka T-63812 (field \# 658): 15.

Gallatly 560: 12 - Garrett 291: 18; 1406: 9 - Griffith 3795: 20 - Grimes 1207: 12.

Ha Tue 291b: 9; 287c: 12 - Hallier 637: 2; 2295: 11 - Harder et al. 2453: 1 - Hartley 10611: 11 - Henderson 31467: 3 - Henry 1977: 6 - Hoogland 4754: 11 - Hoogland \& Craven 10310: 8 - Hooker \& Thompson 9 p.p.: 10, p.p.: 20 - Hullett 136: 12; 822: 12 - Hutt (field collector Robert McK. Bird) 63.462-1 (field \# 5546): 15.

Jacobs 5517: 12 - Johns 9792: 12 - Johns et al. 6792: 11.

Kerr 624: 11; 1294: 17; 1294A p.p.: 17, p.p.: 19; 2568: 9; 6436: 19; 7775: 19; 12370: 2; 13692: 11; 15918: 3; 16068: 12; 16417: 9; 16640: 3; 17130: 8; 17342: 9; 17919: 9; 18679: 3; 18959: 3 — King's collector 5751: 3; 6691: 8 - Kloss 6721:2; 6805: 2; 10590: 8 - Kostermans 60: 2 - Krempf 1562: 11 - Kuswata \& Soepadmo 150: 8.

LAE 66540 (Barker \& Vinas): 12 - Lakshiahaier 325: 2 - Lam 2737: 8 - Lau 1704: 9 - Liew 367: 9 - Livshultz 99-7: 9; 99-161: 17; 99-245: 3; 00-188: 13; 00-200: 17; 01-23: 15; 01-24: 15; 01-29: 7; 02-18: 2; 02-22: 1; 02-50: 4; 02-53: 5; 03-4: 9; 03-11: 4; 03-12: 9; 03-18:12; 03-22: 6; 03-40: 4; 03-42: 8 - Lörzing 5102: 12; 5431: 8 - Lütjeharms 4030: 8 - LX-VN 449: 8; 658: $7 ; 3162: 1$.

Macgillivray 501: 12 - Maingay 1115: 9; 1117: 11; 1120: 8; 1122: 2; 1957: 12; 2992: 9 - Marcan 151: 8 - Martin 218: 12; 460: 8; 1899: 9 - Mason 134: 8 - Maxwell 75-394: 12; 76-732: 12; 78-332: 14; 87-388: 2; 87-841: 17; 89-774: 9; 89-1106: 17; 90-449: 9; 90-574: 12; 90-636: 12; 901295: 19; 91-513: 9; 93-953: 17; 93-1127: 19; 95-136: 9; 96-1248: 19 - Merrill 7200: 13; 8243: 12; 8320: 13; 9367: 9; 11614: 12 - Millar 9725: 8 - Morse 486: 1 - Motley 533: 3; $928: 9$.

Nair 3654: 12 - NGF 39462 (Streimann): 12; 48607 (Millar): 11.

Olsen 26: 9; 487: 9 - Otto-Surbeck 327: 9.

Parker 2712: 2 - Pételot 387: 1; 917: 1; 8965: 12 - Phuc 106: 8 - Phuong 1962: 18; 5151: 1 - Pierre 79 p.p.: 8, p.p.: 11; 3421: 3; 3536: 11; 3863: 3; 4521: 3; 4522: 11 - Pl. Rumph. Amb. 88 (Robinson): 12; 93 (Robinson): 8 - Poilane 67: 18; 3286: 11; 4385: 19; 5826: 12; 10166: 1; 10294: 1; 11230: 8; 11517: 1; 12136: 4; 18007: 15; 22199: 12; 28421: 15; 29812: 1 - PPI 1259 (Reynoso et al.): 11; 2735 (Madulid et al.): 11; 13215 (Gaerlan et al.): 11 - Purseglove 4068: 12; 4444: 3; 4921: 11; 4922: 12 - Put 551: 8; 2363: 3; 2984: 15; 3010: 15; 3164: 3; 3456: 19.

Rahmat si Boeea 2178: 12; 2440: 3 - Ramos 15129: 8; 20413: 8; 21973: 8; 22460: 13 - Ridsdale 1664: 9; 33507 p.p.: 11, p.p.: 12 - Rintz 30: 14; 104: 16;132: 9 - Robertson 291: 11 - Robinson 1474: 1 .

SAN 66637 (Gibot): 11 - Sands et al. 917: 8; 2100: 8 - Schlechter 18425: 12; 18464: 8 - Schodde 2652: 11; 2913: 11 - Scortechini 1077: 8 - SFN 33482 (Corner): 9 - Md. Shah \& Noor 651: 16 - Siew Wei Hoe 88: 14; 198: 14 - Smith 220: 8 - Smitinand \& Sleumer 1269: 9 Sørensen et al. 2770: 17 - Spare 935: 11 - Spire 240: 12 - Stone 5832: 12; 9489-A: 14; 13775: 14; 14127: 14.

Teruya 1170: 2 - Teijsmann 11318: 9 - Thorel 1961: 11 - Tixier 20: 12 - Toroes see Rahmat si Boeea - Tsang 29209: 18.

Van Beusekom \& Charoenpol 1767: 19 - Van Beusekom \& Phengkhlai 281: 2 - Van Beusekom \& Santisuk 2726: 2; 2845: 9; 2913: 7 - Van Niel 3713: 12; 3929: 12 - Versteeg 1925: 12 - Vink 11281: 8; 15210: 8 .

Wallich 551: 3 - Winkler 2552: 8 - Womersley \& Lam 6228: 12 - Wood 1925: 11.

Zollinger 473: 12; 676: 9; 944: 3; 2894: 3 . 